\title{
Library Service on the Berkeley Campus, University of California
}

\author{
$M r$. Leupp is librarian of the University \\ of California Library, Berkeley.
}

\section{$\mathrm{T}$}

He University of California pursues its multiform activities on seven campuses. Each campus has its own library, administered locally in accordance with local requirements. The two large units, in Berkeley and Los Angeles, render assistance, when desired, to the smaller ones and also cooperate with each other in many matters when the five hundred miles separating them does not impose independent action. The largest campus is that of the parent institution at Berkeley, which also possesses the largest library, with holdings of about $1,195,000$ volumes at present. It is with the rather complex organization of library service on the Berkeley campus that this paper deals.

The campus is a roughly oblong tract of about 593 acres, on which the buildings are fairly well distributed, As in most universities which follow a building plan, the older buildings antedate the plan, while those erected subsequently have been located, and in most cases constructed, without much reference to the need or possibility of library service to the departments which occupy them. As a result, until recently, library facilities in buildings at a distance from the General Library usually have "just growed," like
Topsy, while in other cases they have mushroomed into sizable if not always very healthy growth from artificial stimuli of various kinds, such as gifts for specific purposes, federal appropriations, foundation grants, etc. Separatist tendencies, traditional in some departments and in others deriving from the influence of some strong-minded individual on the faculty, also have contributed to the picture.

The Standing Orders of the Board of Regents make the following provisions:

The General Library and the several departmental libraries together shall constitute the university library. ... Departmental libraries shall be considered part of the working equipment of the departments to which they are attached, to be provided in the same manner as other equipment, viz., by purchase with funds allowed the departments in the annual budget or with special funds otherwise available for the use of the departments.

Departmental libraries are under the control of their respective departments, not under that of the General Library. General Library funds may not be used to purchase books for them, although the librarian may deposit in a departmental library, subject to recall, General Library books which "may be required exclusively in the work of the department concerned." The librarian is also instructed to "record" all books acquired by a depart- 
mental library, which in practice means that all departmental books are entered in the General Library catalog. Since the General Library is the purchasing agent for all books ordered by any library on the campus, cataloging for these libraries is a simple matter of routine, which includes furnishing copies of the catalog cards for their books, at cost, to any libraries which may want them.

It will be noted that the standing orders recognize only a General Library and an unspecified number of departmental libraries. Some of the latter without material change have evolved into college or school libraries, as engineering, architecture, and jurisprudence libraries. When the library of one department, agriculture, merged with the General $\mathrm{Li}$ brary some years ago, it retained certain divisional collections, notably entomology and landscape design. All of these, for practical purposes, are regarded as departmental libraries.

\section{Special Libraries}

A very important group of libraries has come into being, all but one within recent years, the existence of which is not recognized in the standing orders at all. These are known collectively as "special libraries." Their distinguishing characteristic is that they are not organically connected with any department but are independently administered, with budgets of their own. The most important are the Bancroft Library of material relating to the West Coast, the Bureau of Public Administration and Library of Economic Research, and the Library of the Giannini Foundation for Agricultural Research. The first two are housed (and very much cramped) in the General $\mathrm{Li}$ - brary building; the Giannini Foundation occupies a building of its own. The General Library purchases and catalogs the books ordered for the special libraries as it does for the departmental libraries.

When in I9I I the General Library was moved to the building it now occupies, the departmental library situation was very unsatisfactory. Conditions which developed during and immediately following World War I made it worse. Nearly every department had its library, varying in size from a dozen or two books in a department office or seminar room to collections of several hundred volumes in chemistry or mining or to libraries embracing almost everything possessed by the university in their fields, such as law and architecture. Because of inadequate facilities, sometimes from plain cussedness, a would-be reader not connected with a department often was made to feel distinctly unwelcome if he ventured into the departmental library. Some departments limited access to their books to members of their own faculties and favored graduate students; in some, even members were excluded unless the head happened to be around and had the key in his pocket. In most departments in which supervision was attempted at all, it was made the responsibility of a clerical assistant or stenographer with other and invariably more pressing duties. Few departments attempted systematically to keep their collections abreast of the times; those which did, notably the premedical departments, were continually in a state of exasperation arising from conflicting demands for the same expensive books and periodicals and insufficiency of funds for the extensive duplication which seemed to offer the only remedy. 
As the situation was studied, certain phenomena emerged. The scientific and technical departments were the principal sufferers from the existing inadequacies. Without exception, they occupied buildings at a distance from the General Library building. Much of their work was done in laboratories or with machines and tools fixed as to location. These phenomena were common to the departments in these groups and were not found to any extent in other departments. Moreover, the literature of interest to these departments, while in large part common to two or more of them, was little in demand by members of other departments or by general readers, differing therein from the literature of, say, the social sciences or the humanities. These considerations led to the conception of still another type of library not recognized by the standing orders, which, in the one group where it has been in operation for nearly thirteen years, has proved so remarkably successful that its extension to other groups of scientific and technical departments is assured. This is the "branch library."

\section{Biology Group}

In 1930 the departments constituting the biology group abandoned the temporary buildings in which they had been distributed over the campus and came together in a building especially designed for them, the Life Sciences Building. There are ten of these departments, plus certain related entities such as the $\mathrm{Mu}$ seum of Vertebrate Zoology and the Herbarium. Nearly every department had its departmental library. When the building was planned the General Library asked for and obtained an assignment of space, centrally located, for a branch library to serve the group. Some of the assigned space was withdrawn before the building was finished, diminishing the projected reading room facilities uncomfortably; but enough was left to provide a stack area with a capacity of about Ioo,00o volumes and facilities, in reading rooms and stack area, for 180 readers. The departments pooled their libraries; the books and periodicals in corresponding classifications were transferred en masse from the General Library (except multiple copies in the rental-reserve service), and the General Library provided the staff. With minor variations due to local conditions, the hours are the same as those of the General Library. The branch librarian is advised by a faculty committee selected from the biology group and appointed by the chairman of the Library Committee of the General Library. The branch committee is always represented by at least one member on the parent committee.

\section{Education Collection}

There is one other branch library, in the department of education. When the department occupied its present building in 1924, the General Library was asked to take jurisdiction of and to administer the departmental library. The General Library did so, largely as an experiment. The experiment will not be repeated. A single department is too small a unit to justify the cost of branch organization, and the literature of education, even if room could be found in the branch for the General Library holdings, is not the kind which should be separated from the main collection. A good deal about the principles underlying partial decentralization by branch libraries was learned from this mistake.

The next branch library undoubtedly 
will be opened in the engineering group. The program has been approved, but nothing can be done until the second and main building of the group is erected. The plans for this provide an entire floor for a library. The departmental library, which consists of the merged libraries of the three engineering departments, occupies an insufficient area in a badly overcrowded building, and funds are lacking to keep it open on full schedule. The much larger technical collection in the General Library cannot be merged with the departmental collection until more space is available and would not be in any case until a full schedule of hours is assured.

\section{Branch Library Purposes}

Other departmental groups seem to offer opportunity for extension of the branch library program, though definite planning has not been carried beyond an engineering branch. In general, the tests applied to any proposed grouping of departments for branch library purposes will be these: Is a considerable body of literature common to two or more of them, and is each of them included in one or more such groupings? Can the common literature and the literature of the individual departments be separated from the main collection without interfering materially with other departments or individuals? Is the work of the departments so related to laboratories, shops, or drafting rooms, or their equivalents, or is the time of students so scheduled with respect to laboratory periods, etc., that a considerable body of literature close at hand is a necessity? Distance from the General Library building, unless excessive, would not in itself be held to justify the expense of branch library installation and maintenance.
Of the departmental libraries which still exist, few are important. The smaller ones have become mere office or seminar room collections which, for the most part, duplicate material in the main collection. Of those in departmental buildings, the law library has but a fraction of the space it needs but is well administered. Architecture is fairly well housed, less well administered. Both the law and architecture departments have independent funds for library maintenance. The chemistry, physics, and mining libraries are adequately administered. The chemistry and physics departments are interested only in the latest literature of their subjects, which they obtain largely from the General Library on deposit, and their needs conflict to some extent. Fortunately the libraries are close together. Neither has much room, and neither is hospitable to visitors. The libraries of geological sciences and of mining are almost wholly duplicated in the General Library. It has been the policy of the mining and engineering libraries to order for the General Library, from its allotment, a copy of every significant book purchased from departmental funds for its own library. The departmental library of agriculture was discontinued in 1919, and most of its books were transferred to the General $\mathrm{Li}$ brary, which agreed to maintain an agricultural reference librarian and provide certain reading room space for agriculture students, with adjoining shelving for reference books, journals, etc., of interest to them. The plan has not worked wholly to the satisfaction of the department, as increasing demand for reading room facilities makes it difficult for the agriculture students to maintain their segregated area. Agriculture would like to move from the General Library building to the biology 


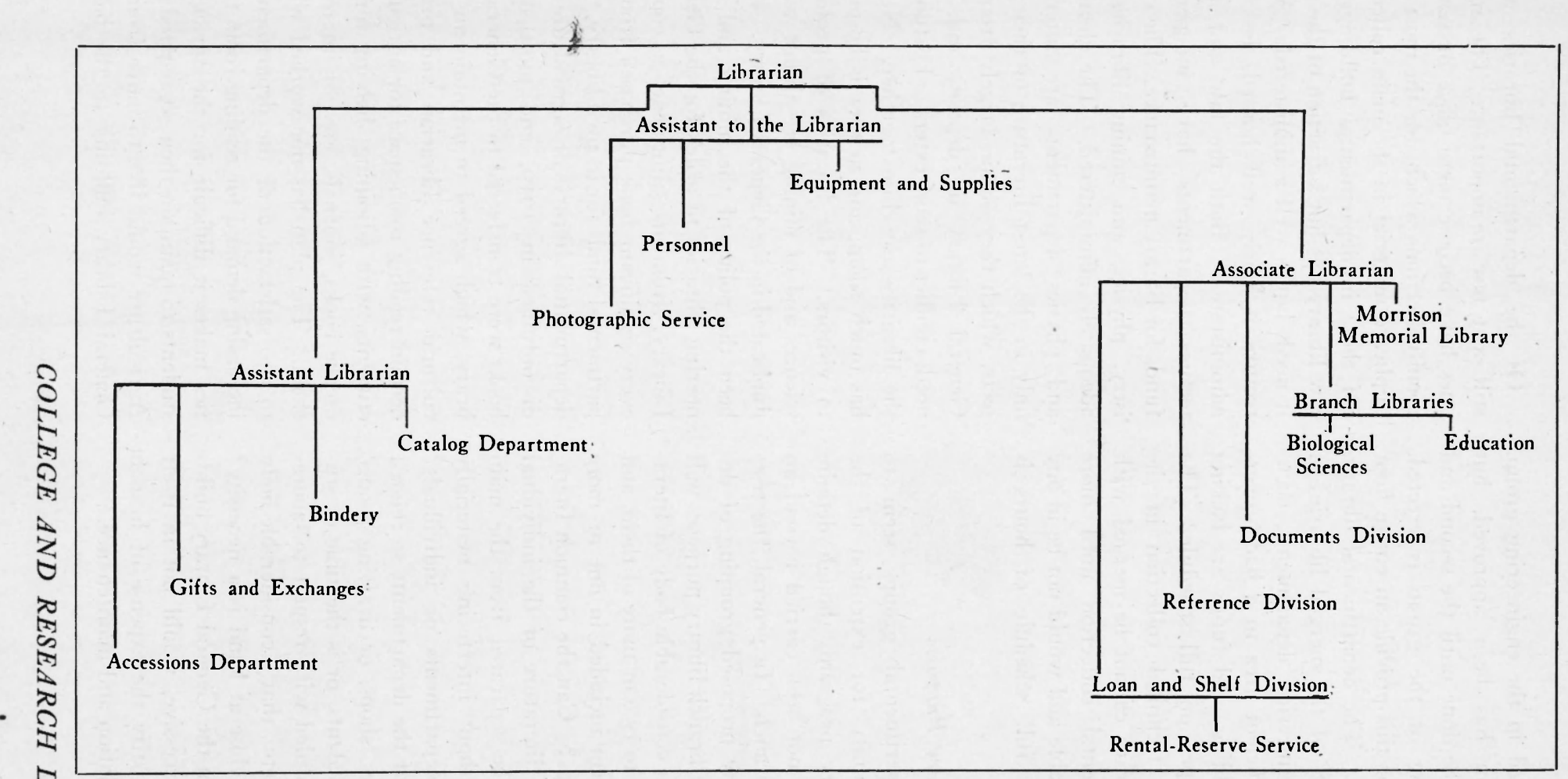

Organization Chart of the University of California Library, Berkeley 
library, where material related to its own is now housed and which is considerably nearer the agriculture group. While the books could be cared for in the biology library, there is, unfortunately, no room for the students.

\section{General Services}

Turning now to the General Library, the loan desk, on the second or main floor at the entrance to the stack enclosure, is the headquarters of the loan and shelf division. This division handles all loans, including interlibrary loans, except those of unbound periodicals and material in pamphlet form, maps, and rare or restricted books. The handling of these is a function of the reference division, which is responsible for both the reference and the periodical desk. The loan division also administers the rental-reserve service on the ground floor just inside the main entrance of the building. To many undergraduate and most lower division students this service is the most, if not the only, important part of the library. In normal times the rental-reserve service does a greater volume of business than the loan and periodical desks together. Now it is barely active, a minor casualty of the war. Facing the rental-reserve room across the entrance hall is the A. F. Morrison Memorial Library, a room for recreational reading, beautifully and comfortably furnished and equipped with books by May Treat Morrison of the class of ' 78 in memory of her husband, a classmate. Dedicated in 1928 to the use of registered students of the university, it has grown steadily in popularity. In the last year before war altered the picture, the 15,000 books on its open shelves had more than 59,000 readers. The room is now open to men in uniform, and many come in to read and relax in its atmosphere of repose.

All of these services, together with the documents division, are under the supervision of Associate Librarian Jerome K. Wilcox, who also keeps a fatherly eye on the two branch libraries. Under Assistant Librarian Jens Nyholm's supervision fall the accessions and catalog departments, the division of gifts and exchanges, and all bindery work, including both preparation of material for the university bindery and the newspaper and pamphlet binding, repair work, etc., done on the premises. This organization divides library operations into the services of acquisition and preparation on the one hand and the public services on the other, each under a coordinating and supervisory head responsible directly to the librarian. Its effect has been to break down the invisible but effective walls which independent departments so often tend to erect about themselves and to insure harmonious action within each group, reducing friction, duplication of effort, and lost motion.

\section{Staff Meetings}

Articulation between the groups is insured by frequent meetings with the librarian of what may be termed the general staff of the library: Mr. Wilcox, Mr. Nyholm, and the assistant to the librarian, Mrs. Elinor Hand Hickox. Mrs. Hickox combines in herself the functions of personnel officer, manager of the photographic services (photostat, microfilm, and dexigraph), and supervisor of work centering in the librarian's office, such as preparation of pay rolls, ordering and issuing of supplies, looking after repairs to building and furnishings and upkeep of equipment, maintenance of correspondence files, etc. Many difficulties have been ironed out in

(Continued on page 232) 
sponsibility for such internal activities as the selection of part-time and student assistants, building maintenance, the vacation schedule, and supplies and equipment. Prospects for full-time appointments are interviewed jointly.

Aside from the coordination secured through the reporting of one unit to a superior officer, horizontal coordination of activity is sought by means of a fortnightly library council, meeting with the librarian and associate librarian, whose members comprise all those responsible for important units of work. Staff meet- ings held independently by departments or work units are infrequent since the number of individuals in such groups is small and because, for the most part, they work at adjacent desks. The absence of adjacency, however, has prompted those in charge of loan work (in branches, loan department, periodical room, etc.) to meet together from time to time to discuss related problems. Recommendations proceed from this body to the librarian, to the associate librarian, or to a department head, depending on the nature of the problem.

\section{Library Service on the Berkeley Campus}

\section{(Continued from page 217)}

these conferences, many ways and means devised, and many undertakings initiated and planned in detail before being launched. In particular, and this has proved important in this time of frequent emergencies and constant unprecedented demands upon resources and personnel, they have insured a thorough understanding by the executives of the aims and the policies of the library, both in its capacity as a vital organ of the university, necessary to its proper functioning, and as an agency active in forwarding the country's war effort. That has meant teamwork. 